\title{
Emotional Maturity of Pharmaceutical and Engineering
}

\section{Company Employees}

\author{
Jashvantbhai B. Devda*, Dr. S.M. Makvana**
}

\section{ABSTRACT}

Aim of the research is to find out the emotional maturity among pharmaceutical and engineering company employees so investigator selected three groups one is type of organization, second is category of employee and third is education qualification, the groups have 300 peoples. In each group has 150 pharmaceutical employees and other one groups has 150 engineering employees. Scale was use for data collection is personal datasheet and Emotional quotient test scale developed by dilipsingh and nkchadha (2003), 2x2x3 factorial design was used and data were analysis by ' $F$ ' test. Result show, There is significant difference between the emotional maturity among pharmaceutical and engineering company employees. The emotional maturity of engineering company employees is better than pharmaceutical company employees. There is no significant difference between the emotional maturity among manager and worker of pharmaceutical and engineering company employees. There is significant difference between the emotional maturity among post-graduate, graduate and diploma of pharmaceutical and engineering company employees. The emotional maturity of post-graduate employee is better than graduate, the diploma holder employee is better than graduate and the post-graduate employee is better than diploma holder employee. There is no significant interaction effect of the emotional maturity among types of organization and category of employees of pharmaceutical and engineering company employees. There is no significant interaction effect of the emotional maturity among types of organization and education qualification of pharmaceutical and engineering company employees. There is significant interaction effect of the emotional maturity among category of employee and education qualification of pharmaceutical and engineering company employees. There is significant interaction effect of the emotional maturity among types of organization, category of employees and education qualification of pharmaceutical and engineering company employees.

\section{Keywords: Emotional Maturity}

\footnotetext{
*Research Scoler, Dept. of Psychology, Sardar Patel University, VVN, India

**Prof. Dept. of Psychology, Sardar Patel University, VVN, India
}

(C) 2014 J Devda, S Makvana; licensee IJIP. This is an Open Access Research distributed under the terms of the Creative Commons Attribution License (http://creativecommons.org/licenses/by/2.0), which permits unrestricted use, distribution, and reproduction in any Medium, provided the original work is properly cited. 


\section{INTRODUCTION}

Etymologically the word 'Emotion' is derived from the Latin word Emovere' which means to stir up, to excite or to agitate. Emotional maturity implies understanding of oneself, Understanding of the word and understanding of realities of life. Most of our emotional problems arise because we have not understood ourselves and our needs. Whenever there is an emotional situation, it implies an unmet need. By understanding ourselves and connection to our feeling and needs, we can fulfill our needs as well as grow into a mature person. Emotional Maturity implies controlling one's emotions rather than letting our emotions get the better of us. Our emotional maturity depicts our capacity to manage and to check our emotions to evaluate others' emotional state and to persuade their judgment and actions. A person's emotional maturity is very much influenced by his/her relationship history. Emotional intelligence makes an important part of life, together with intellectual and relationship intelligence. Such intelligence can help one to assess emotional maturity and emotional freedom. How well we can tackle any relationship, is a major discernible factor to check our level of emotional maturity.

According to Charles E. Skinner (1949), an emotionally mature person is one who is able to keep a lid on his feelings. He can suffer in silence; he can bid his time in spite of present discomfort. He is not subject to swings in mood, he is not volatile. When he does express emotion, he does so with moderation, decency and in good order.

According to Walter D. Smitson (1974), "Emotional Maturity is a process in which the personality is continuously striving for greater sense of emotional health, both intra-physically and intra-personally."

According to Crow and Crow (1974), "An emotion is an affective experience that accompanies generalized inner adjustment and mental and psychologically stirred up states in an individual and that shows itself in his overt behavior."

According to Coleman (1944), "The most outstanding make of emotional maturity is the ability to bear tension. Besides, an emotionally matured person persists in the capacity of fun and recreation. He enjoys both play and responsible activities and keeps them in proper balance." According to Fred Mc. Kinney (1960), "The characteristics of an emotionally matured person are heterosexuality, appreciation of attitude and behavior of others tendencyto adopt the attitude and habits of others and capacity to delay own responses".

The emotional maturity is best defined as our ability to become sensitive to our environment and the people we interact with. Our perceived emotions allow us the ability to control situations and create solutions. This emotional maturity is also known as having a sense of self. 


\section{AIMS OF THE STUDY:}

1. To study of emotional maturity among pharmaceutical and engineering company employees.

2. To study of emotional maturity among manager and worker of pharmaceutical and engineering company employees.

3. To study of emotional maturity among post-graduate, graduate and diploma degree holder of pharmaceutical and engineering company employees.

4. To study of the effect of interaction on emotional maturity among type of organization and category of employee of pharmaceutical and engineering company employees.

5. To study of the effect of interaction on emotional maturity among type of organization and education qualification of pharmaceutical and engineering company employees.

6. To study of the effect of interaction on emotional maturity among category of employee and education qualification of pharmaceutical and engineering company employees.

7. To study of the effect of interaction on emotional maturity among type of organization, category of employee and education qualification of pharmaceutical and engineering company employees.

\section{HYPOTHESIS:}

1. There is no difference between the emotional maturity among pharmaceutical and engineering company employees.

2. There is no difference between the emotional maturity among manager and worker of pharmaceutical and engineering company employees.

3. There is no difference between the emotional maturity among post-graduate, graduate and diploma degree holder of pharmaceutical and engineering company employees.

4. There is no interaction effect of the emotional maturity among types of organization and category of employees of pharmaceutical and engineering company employees.

5. There is no interaction effect of the emotional maturity among types of organization and education qualification of pharmaceutical and engineering company employees.

6. There is no interaction effect of the emotional maturity among category of employee and education qualification of pharmaceutical and engineering company employees.

7. There is no interaction effect of the emotional maturity among types of organization, category of employees and education qualification of pharmaceutical and engineering company employees.

\section{METHODOLOGY:}

\section{Research design:}

This research will be adopted $2 \times 2 \times 3$ factorial design as well as $1^{\text {st }}$ is type of organization (Pharmaceutical and Engineering), $2^{\text {nd }}$ is type of employees (Manager and Worker) $3^{\text {rd }}$ is education qualification (Post-Graduate, Graduate and Diploma). 


\begin{tabular}{|l|l|l|l|l|l|l|l|}
\hline Samples & \multicolumn{3}{|l|}{ B1 } & B2 & \\
& \multicolumn{2}{|l|}{$\begin{array}{l}\text { Total no. of } \\
\text { samples }\end{array}$} \\
\cline { 2 - 9 } & C1 & C2 & C3 & C1 & C2 & C3 & \\
\hline A1 & 25 & 25 & 25 & 25 & 25 & 25 & $\mathbf{1 5 0}$ \\
\hline A2 & 25 & 25 & 25 & 25 & 25 & 25 & $\mathbf{1 5 0}$ \\
\hline $\begin{array}{l}\text { Total no. of } \\
\text { samples }\end{array}$ & 50 & 50 & 50 & 50 & 50 & 50 & $\mathbf{3 0 0}$ \\
\hline
\end{tabular}

1. A1- Means pharmaceutical company.

2. A2- Means engineering company.

3. B1- Means Manager.

4. B2- Means Worker.

5. C1- Means post-graduate education qualification.

6. C2- Means graduate education qualification.

7. C3-Means diploma education qualification.

SAMPLE:

The sample comprised of total 300 employees of pharmaceutical and engineering companies. The sample selected randomly from the various pharmaceutical and engineering companies.

\section{TOOLS USED:}

The following tools were used in the present study:

\section{- Personal Datasheet:}

A Personal data sheet developed by investigator will used to collect information about types of organization, category of employee and education qualification.

\section{- Emotional quotient test:}

This test standardize and developed by dilipsingh and nkchadha (2003), the test contains 22 items. The present EQ test measures three psychological dimensions such as emotional sensitivity, emotional maturity and emotional competency.

\section{RELIABILITY:}

For the present scale, test-retest and split-half reliabilities were computed. To find the 'retest reliability' a sample of 150 (males and females) was taken. The retest reliability for the test was found to be 0.94 . The 'split-half' is another method of estimating reliability coefficient. It measures internal consistency of test scores. The split-half reliability in the case of odd-even items was 0.89 and for the first half and second half was 0.91 . Both reliability coefficients are significantly higher which indicate that the present EQ scale enjoys high reliability. 


\section{VALIDITY:}

The test, designed by danielgoleman, and the present scale was administered to 60 subjects. The scores obtained from both tests were correlated to determine the validity index. The validity was found to be 0.92 , which indicates that the present EQ scale is valid. Further, the present scale was co-related with the emotional intelligence test developed by chadha (2001) on 60 subjects to determine the validity index. The validity was found to be 0.78 which indicates that the present test is valid.

\section{STATISTICAL ANALYSIS:}

Following statistical analysis will be used for analyzing the data.

F-ANOVA

\section{RESULT AND DISCUSSION:}

Emotional maturity with reference type of organization, category of employees and education qualification

The main objective was to study pharmaceutical and engineering organization employees having category manager and worker also having educational qualification of post-graduate, graduate and diploma degree differ in overall emotional maturity. In this context, 7 null hypotheses (no.1to7) were constructed. For this purpose $2 \times 2 \times 3$ factorial design was framed. To examine these null hypothesis statistical techniques of F- ANOVA was used. The results obtained are presented in table 1,2, and 3.

Table no. $1(\mathbf{N}=300)$

Means and SDs of overall emotional maturity with reference type of organization, category of employees and education qualification.

\begin{tabular}{|c|c|c|c|c|c|}
\hline \multicolumn{3}{|c|}{ Independent variable } & \multirow{2}{*}{$\begin{array}{l}\text { Post- } \\
\text { Graduate } \\
110.96\end{array}$} & \multirow{2}{*}{\begin{tabular}{|l|} 
Graduate \\
93.44 \\
\end{tabular}} & \multirow{2}{*}{$\begin{array}{l}\text { Diploma } \\
93.60\end{array}$} \\
\hline \multirow[t]{5}{*}{ Pharmaceutical } & \multirow[t]{3}{*}{ Manager } & Mean & & & \\
\hline & & SD & 10.00 & 25.26 & 18.68 \\
\hline & & $\mathrm{N}$ & 25 & 25 & 25 \\
\hline & \multirow[t]{2}{*}{ Worker } & Mean & 94.40 & 91.20 & 106.44 \\
\hline & & SD & 12.61 & 16.09 & 24.39 \\
\hline
\end{tabular}


Emotional Maturity of Pharmaceutical and Engineering Company Employees

\begin{tabular}{|l|l|l|l|l|l|}
\hline & & $\mathrm{N}$ & 25 & 25 & 25 \\
\hline Engineering & \multirow{3}{*}{ Manager } & Mean & 116.40 & 112.60 & 116.80 \\
\cline { 3 - 6 } & & SD & 11.41 & 11.38 & 7.89 \\
\cline { 3 - 6 } & $\mathrm{N}$ & 25 & 25 & 25 \\
\cline { 3 - 6 } & \multirow{3}{*}{ Worker } & Mean & 114.58 & 112.40 & 112.40 \\
\cline { 3 - 6 } & & SD & 10.42 & 12.17 & 11.00 \\
\cline { 3 - 6 } & & N & 25 & 25 & 25 \\
\hline
\end{tabular}

Table no. $2(\mathrm{~N}=300)$

Difference between mean score of overall emotional maturity with reference type of organization, category of employees and education qualification.

\begin{tabular}{|c|c|c|c|}
\hline Independent variable & $\mathrm{N}$ & Mean (M) & $\begin{array}{c}\text { Difference } \\
\text { between mean }\end{array}$ \\
\hline Pharmaceutical(A1) & 150 & 98.25 & \multirow[t]{2}{*}{$16.02(\mathrm{~A} 1 \times \mathrm{A} 2)$} \\
\hline Engineering(A2) & 150 & 114.27 & \\
\hline Manager/supervisor(B1) & 150 & 107.21 & \multirow[t]{2}{*}{ 1.9(B1 x B2) } \\
\hline Worker(B2) & 150 & 105.31 & \\
\hline Post-Graduate(C1) & 100 & 109.05 & \multirow{3}{*}{$\begin{array}{l}6.64(\mathrm{C} 1 \times \mathrm{C} 2) \\
4.9(\mathrm{C} 2 \times \mathrm{C} 3) \\
1.74(\mathrm{C} 1 \times \mathrm{C} 3)\end{array}$} \\
\hline Graduate(C2) & 100 & 102.41 & \\
\hline Diploma(C3) & 100 & 107.31 & \\
\hline
\end{tabular}

Table no.4.3n $(\mathrm{N}=300)$

ANOVA summary of overall emotional maturity with reference type of organization, category of employees and education qualification.

\begin{tabular}{|c|c|c|c|c|c|}
\hline Source of variance & $\begin{array}{c}\text { Sum of } \\
\text { squares }\end{array}$ & $\mathbf{d f}$ & $\begin{array}{c}\text { Mean } \\
\text { sum of } \\
\text { squares }\end{array}$ & $\mathbf{F}$ & $\begin{array}{c}\text { Sign. } \\
\text { Level }\end{array}$ \\
\hline Type of organization & 19248.03 & 1 & 19248.03 & 82.65 & $0.01^{*}$ \\
\hline Category of employee & 270.75 & 1 & 270.75 & 1.16 & NS \\
\hline
\end{tabular}


Emotional Maturity of Pharmaceutical and Engineering Company Employees

\begin{tabular}{|c|c|c|c|c|c|}
\hline Education qualification & 2370.91 & 2 & 1185.45 & 5.09 & $0.01^{*}$ \\
\hline $\begin{array}{c}\text { Type of organization } x \text { Category of } \\
\text { employee }\end{array}$ & 0.75 & 1 & 0.75 & 0.003 & NS \\
\hline $\begin{array}{c}\text { Type of organization } x \text { Education } \\
\text { qualification }\end{array}$ & 669.44 & 2 & 334.72 & 1.44 & NS \\
\hline $\begin{array}{c}\text { Category of employee } x \text { Education } \\
\text { qualification }\end{array}$ & 2103.92 & 2 & 1051.96 & 4.52 & $0.05^{* *}$ \\
\hline $\begin{array}{c}\text { Type of organization } \times \text { Category of } \\
\text { employee } x \text { Education qualification }\end{array}$ & 3215.12 & 2 & 1607.56 & 6.90 & $0.01^{*}$ \\
\hline SSW (Error) & 67074.32 & 288 & 232.90 & & \\
\hline SST $\quad * P>0.01, * * P>0.05, N S=$ Not Significant & & \\
\hline
\end{tabular}

\section{Emotional maturity with reference to type of organization:-}

When $\mathrm{F}$ test was applied to check the impact of emotional maturity on type of organization, significant $\mathrm{F}$ value was found. The $\mathrm{F}$ value (table no.3) is 82.65 which are statistically significant on level 0.01. Table no. 2 reveals that the mean scores of emotional maturity of pharmaceutical company employees is 98.25 and engineering company employees is 114.27 respectively and the mean difference between two is 16.02 which is very high and not negligible. Hence the null hypothesis 1 was rejected and it was concluded that there was significant impact of emotional maturity on pharmaceutical and engineering company employees.

\section{Emotional maturity with reference to category of employee :-}

When $\mathrm{F}$ test was applied to check the impact of emotional maturity on Category of Employee, no significant $\mathrm{F}$ value was found. The $\mathrm{F}$ value (table no.3) is 1.16 which is statistically not significant. Table no. 2 reveals that the mean score of emotional maturity of manager and is 107.21 and worker is 105.31 as respectively and the mean difference between two is 1.09 which is very negligible. Hence, the null hypothesis 2 was maintained and it was conclude that there was not any significant impact of emotional maturity on manager and worker.

\section{Emotional maturity with reference to education qualification:-}

When $\mathrm{F}$ test was applied to check the impact of emotional maturity on education qualification, significant $\mathrm{F}$ value was found. The $\mathrm{F}$ value (table no.3) is 5.09 which are statistically significant on level 0.01 . Table no. 2 reveals that the mean scores of emotional maturity of post-graduate is 109.05 , graduate is 102.41 and diploma is 107.31 respectively and the difference between two is $6.64(\mathrm{C} 1 \times \mathrm{C} 2), 4.9(\mathrm{C} 2 \times \mathrm{C} 3)$ and $1.74(\mathrm{C} 1 \times \mathrm{C} 3)$ which is very high and not negligible. Hence the null hypothesis 3 was rejected and it was concluded that there was significant impact of emotional maturity on post-graduate, graduate and diploma. 
Emotional maturity with reference to interaction effect of type of organization and category of employee:-

When $\mathrm{F}$ test was applied to check the interaction effect of emotional maturity on type of organization and category of employee, no significant interaction effect was found. The F value (table no 3) is 0.003 which is statistically not significant. Hence the null hypothesis 4 was maintained and it was conclude that there was no significant interaction effect of emotional maturity on type of organization and category of employee.

Emotional maturity with reference to interaction effect of type of organization and education qualification:-

When $\mathrm{F}$ test was applied to check the interaction effect of emotional maturity on type of organization and education qualification, no significant interaction effect was found. The F value (table no 3) is 1.44 which is statistically not significant. Hence the null hypothesis 5 was maintained and it was conclude that there was no significant interaction effect of emotional maturity on type of organization and education qualification.

Emotional maturity with reference to interaction effect of category of employee and education qualification:-

When F test was applied to check the interaction effect of emotional maturity on category of employee and education qualification, significant $F$ value was found. The F value (table no 3 ) is 4.52 which are statistically significant on level 0.05 . Hence the null hypothesis 6 was rejected and it was concluded that there was significant interaction effect of emotional maturity on category of employee and education qualification.

Emotional maturity with reference to interaction effect of type of organization, category of employee and education qualification:-

When $\mathrm{F}$ test was applied to check the interaction effect of emotional maturity on type of organization, category of employee and education qualification, significant $\mathrm{F}$ value was found. The F value (table no 3 ) is 6.90 which are statistically significant on level 0.01 . Hence the null hypothesis 7 was rejected and it was concluded that there was significant interaction effect of emotional maturity on type of organization, category of employee and education qualification.

\section{CONCLUSION:}

1. There is significant difference between the emotional maturity among pharmaceutical and engineering company employees. The emotional maturity of engineering company employees is better than pharmaceutical company employees.

2. There is no significant difference between the emotional maturity among manager and worker of pharmaceutical and engineering company employees. 
3. There is significant difference between the emotional maturity among post-graduate, graduate and diploma of pharmaceutical and engineering company employees. The emotional maturity of post-graduate employee is better than graduate, the diploma holder employee is better than graduate and the post-graduate employee is better than diploma holder employee.

4. There is no significant interaction effect of the emotional maturity among types of organization and category of employees of pharmaceutical and engineering company employees.

5. There is no significant interaction effect of the emotional maturity among types of organization and education qualification of pharmaceutical and engineering company employees.

6. There is significant interaction effect of the emotional maturity among category of employee and education qualification of pharmaceutical and engineering company employees.

7. There is significant interaction effect of the emotional maturity among types of organization, category of employees and education qualification of pharmaceutical and engineering company employees.

\section{REFERENCES:}

1. Joshi,R. and Tomar, S.,(2010).A study of optimism and Pessimism on emotional Maturity, depression and coping Strategies among adolescent, international research journal, vol. I issue- $3 \& 4$

2. Singh, R., (2011). Emotional maturity among senior secondary school students in relation to their self-esteem, home environment and mental health, Ph.D. Thesis Education, Published maharshiday anand university, rohtak, hariyana.

3. Srilatha, B.,(2012).Emotional maturity, social maturity and moral judgment of the student teachers of guntur district, ph.d. Thesis education, published Acharya Nagarjuna University, nagarjuna nagar, guntur, a.p.

4. Suneetha, H. and Vijayalaxmi, A. A., (2007). Self- Concept, Emotional Maturity and Acievement Motivation of the Adolescent Children of Employed Mothers and Homemakers, Journal of the Indian Academy of Applied Psychology, January 2007, Vol. 33, No.1, 103110.

\section{WEBSITE:}

1. http://shodhganga.inflibnet.ac.in/

2. http://etheses.saurashtrauniversity.edu/ 